\title{
STRATEGI KOMUNIKASI PEMASARAN TERPADU COFFEE SHOP KOPI TULI
}

\author{
1) Adinda Valisha Putri, ${ }^{2)}$ Dini Salmiyah Fithrah Ali \\ ${ }^{1,2)}$ Prodi Ilmu Komunikasi, Fakultas Komunikasi dan Bisnis, Universitas Telkom \\ 1,2) Jl. Telekomunikasi Jl. Terusan Buah Batu, Sukapura, Kec. Dayeuhkolot, Bandung, Jawa Barat \\ E-mail : ${ }^{1 .)}$ dindaong1@ gmail.com ${ }^{2 .)}$ dinidjohan@gmail.com
}

\begin{abstract}
ABSTRAK
Coffee shop kopi tuli merupakan coffee shop pertama di Indonesia yang dikelola oleh kaum disabilitas tuli. Coffee shop kopi tuli memiliki keunikan dari interaksi dengan pelanggan menggunakan bahasa isyarat yang merupakan value yang dapat dimanfaatkan sebagai strategi komunikasi pemasaran. Penelitian ini bertujuan untuntuk mengetahui Strategi Komunikasi Pemasaran Terpadu Coffee Shop Kopi Tuli. Metode penelitian pada penelitian ini adalah deskriptif kualitatif dengan paradigma post positivistik. Pengumpulan data dilakukan melalui observasi, wawancara dan dokumentasi. Teknik Analisis Data berpedoman pada Miles dan Huberman yang terdiri dari pengumpulan data, Reduksi data, Penyajian Data dan Penarikan kesimpulan. Hasil penelitian kegiatan perencaan dari coffee shop kopi tuli dengan menganalisis masalah melalui analisis pasar, SWOT dan competitor, menganalisis khalayak, merumuskan tujuan komunikasi, pemilihan media dan saluran komunikasi serta pengembangan pesan. Pada kegiatan pelaksanaan yaitu melalui kegiatan personal selling, sales promotion, public relation dan publisitas, event dan pengalaman. Kegiatan evaluasi dengan cara mengukur kerja.
\end{abstract}

Kata Kunci: Coffee shop kopi tuli, Komunikasi Pemasaran, Komunikasi Pemasaran Terpadu, Strategi Komkunikasi pemasaran

\section{ABSTRACT}

Coffee Shop Kopi Tuli is the first coffee shop in Indonesia which is managed by deaf people. coffee shop kopi tuli has a unique interaction with customers using sign language which is a value that can be utilized as a marketing communication strategy. This study aims to determine the Integrated Marketing Communication Strategy of Deaf Coffee Shop.The research method in this research is descriptive qualitative with a post positivistic paradigm. Data collection is done through observation, interviews, and documentation. Data Analysis Techniques are guided by Miles and Huberman consisting of merging data, data reduction, data presentation and concluding. collection, data reduction, data presentation and conclusion drawing. The results of research planning activities of the deaf coffee shop by analyzing problems through market analysis, SWOT and competitors, analyzing audiences, formulating communication goals, choosing media and communication channels and developing messages. In the implementation activities namely through personal selling activities, sales promotion, public relations and publicity, events and experience. Evaluation activities by measuring work.

Keyword: Coffee Shop Kopi Tuli, Integrated Marketing Communication, Marketing Communication, Marketing Communication Strategy 


\section{PENDAHULUAN}

\section{A. Latar Belakang}

Kesempatan untuk mendapatkan pekerjaan bagi penyandang disabilitas merupakan sebuah persoalan yang dihadapi disabilitas saat ini. Walaupun Undang Undang pemerintah telah menetapkan adanya kuota $2 \%$ bagi mereka untuk dapat bekerja di perusahaan swasta ataupun dipemerintahan namun hal ini jauh dari yang diharapkan. Penyandang disbilitas dianggap belum mampu untuk memenuhi target yang diinginkan perusahaan, seperti yang dijelaskan oleh Adioetomo, Daniel Mont dan Irwanto (Adioetomo, Daniel Mont, \& Irwanto, 2016) bahwa disabilitas tidak dapat memaksimalkan fungsi sebagai seorang individu di dalam ruang lingkung bermasyarakat.

Penyandang disabilitas merupakan bagian dari masyarakat yang membutuhkan bantuan dalam menjalankan aktivitas kehidupannya yang disebabkan oleh suatu keadaan atau kondisi tubuh atau system syaraf yang dimilikinya. Dalam menghadapi penyandang disabilitas ini masyarakat mempunyai tanggung jawab menghormati, mengayomi serta menerima kehadiran mereka sebagai insan yang mempunyai hak sebagai individu, hal ini ditegaskan dalam Undang-Undang Nomor 39 Tahun 1999 tentang Hak Asasi Manusia. Hak asasi manusia sebagai hak dasar yang secara kodrati melekat pada diri manusia bersifat universal, perlu dilindungi, dihormati, dan dipertahankan, sehingga Pelindungan dan hak asasi manusia terhadap kelompok rentan, khususnya Penyandang Disabilitas

Dalam UU 8 Tahun 2016 juga dijelaskan bahwa penyandang disabilitas merupakan individu yang mengalami keterbatasan fisik, intelektual, mental, dan/atau sensorik dalam jangka waktu lama sehingga dalam berinteraksi dengan lingkungan mengalami hambatan serta mempunyai kesulitan untuk berpartisipasi secara penuh secara normal dengan warga negara lainnya. Hak yang dimiliki oleh penyandang disabilitas meliputi hak-hak yang bersamaan denga hak sebagai warganegara lainnya seperti, kesehatan, pendidikan, hukum dan lainnya. Dalam UU No 8 pasal 11 dijelaskan tentang kesempatan penyandang disabilitas dalam memperoleh pekerjaan yang diselenggarakan oleh Pemerintah, atau swasta tanpa ada diskriminasi, serta memperoleh kesempatan dalam mengembangkan jenjang karier serta segala hak normatif yang melekat di dalamnya.

Coffee Shop Kopi Tuli yang merupakan Coffe Shop dengan konsep modern yang berbeda dari kedai kopi lainnya. Penamaan "Koptul" ini merupakan singkatan dari "Kopi Tuli“. Coffee Shop Kopi Tuli merupakan coffee shop pertama yang dikelola oleh para difabel (Tuli/Tuna Rungu) di Indonesia (Wahid, 2018). Coffee Shop Kopi Tuli, terbentuknya karena sebuah keinginan yang dialami oleh para disabilitas yang menginginkan sebuah pengakuan masyarakat bahwa mereka juga bisa mandiri dan sejajar dengan masyarakat biasa lainnya dalam berkreasi dan berinovasi bekerja dalam mencari penghidupan. Dalam menjalankan usahanya coffee shop kopi tuli menghadirkan ketidaksempurnaan mereka untuk menjadi kekuatan dalam menjalankan usahanya. 
Ketidakmampuan berkomunikasi secara normal dimanfaatkan sebagai kekuatan bagi mereka untuk menarik konsumen dengan cara mengajarkan bahasa isyarat kepada konsumen. Disamping untuk menarik pelanggan mereka berkeinginan juga agar bahasa isyarat menjadi bahasa yang familiar bagi masyarakat. Secara tidak langsung coffee shop kopi tuli memberi edukasi kepada "teman dengar" mengenai cara komunikasi menggunakan bahasa isyarat.

Coffee shop kopi tuli mempunyai cara komunikasi yang unik, yaitu pelanggannya diajarkan belajar bahasa isyarat, sehingga bila pelanggan sudah bisa berkomunikasi isyarat maka kesulitan dalam berkomunikasi dapat teratasi, karena idealnya pesan akan dapat dipahami jika pengirim dan penerima pesan saling mengerti maksud pesan yang disampaikan.

Dari konsep yang sederhana itulah pemilik menerapkan pelayanan kepada pelanggannya. Ketika seseorang sudah terbiasa melakukan aktivitas sehari-hari secara normal, sekarang muncul "New experience" dengan kebutuhan minum kopi serta dapat mengedukasi melalui belajar bahasa isyarat dan komunikasi dengan kaum Tuli/Tunarungu secara langsung.

Era third wave adalah masyarakat sudah antusia terhadap latar belakang kopi hingga proses pembuatan kopi dan kopi sudah dianggap sebagai minuman artisan layaknya wine dimana orang-orang mulai peduli dengan kisah di baliknya (Maharani, 2018). Kondisi tersebut menjadi peluang bagi coffee shop kopi tuli dalam menyampaikan pesan yaitu dari latar belakang coffee shop.

Komunikasi pemasaran yang ditujukan untuk menyampaikan pesan kepada konsumen dengan menggunakan media dan berbagai saluran pemasaran dengan tujuan untuk pemberian informasi, pengenalan produk serta hal yang berkaitan dengan produk tersebut. Strategi komunikasi pemasaran dilakukan dalam menghadapi persaingan dari usaha sejenis dan mencari hal hal yang unik dapat dijadikan untuk menarik konsumen melalui cara yang berbeda. Dengan banyaknya jenis usaha seperti coffee shop saat ini, seorang pengusaha perlu mengenalkan dan mempertahan kelangsungan usaha melalui strategi komunikasi pemasaran yang baik.

Saat ini coffee shop kopi tuli memanfaatkan value yang dimilikinya yaitu Tuli. Dalam setiap kegiatan komunikasi pemasaran pesan yang disampaikan oleh coffee shop kopi tuli itu sama yaitu untuk membuktikan bahwa disabilitas juga bisa mandiri membangun usaha dan memberikan lapangan pekerjaan kepada teman tuli, yaitu dengan tagline "the taste that touch your heart" yang memiliki arti bahwa rasa ini bisa menyentuh hati siapa saja yang datang ke coffee shop kopi tuli melalui experience yang diberikan, dan ini termasuk pada bagian dari komunikasi pemasaran terpadu.

Kegiatan komunikasi pemasaran yang sudah dilakukan oleh coffee shop kopi tuli dapat dilihat aktivitasnya yaitu mengadakan event di store, melakukan promosi secara langsung melalui talk show, melakukan kegiatan public relations dengan komunitas tuli menggunakan bahasa isyarat dan penggunaan media sosial instagram yang menjadi 
platform media sosial utama dalam menyebarkan kegiatan komunikasi pemasaran dari coffee shop kopi tuli. Dalam menunjang kegiatan komunikasi pemasaran Coffee Shop Kopi Tuli juga bekerjasama dengan universitas-universitas dan sekolah-sekolah sebagai pembicara, melakukan workshop di store Kopi Tuli dan menjalin hubungan dengan komunitas tuli Indonesia untuk menyampaikan pesan bahwa disabilitas juga mampu mandiri dan memebuat lapangan pekerjaan bagi disabilitas. Kegiatan-kegiatan komunikasi pemasaran yang dilakukan oleh Coffee Shop Kopi Tuli dipublikasikan melakui media sosial instagram.

Berdasarkan pemaparan diatas coffee shop kopi tuli memiliki keunikan tersendiri dari proses komunikasinya yaitu bahasa isyarat yang digunakan dalam berinteraksi dan juga disabilitas sebagai value yang dimilik oleh coffee shop kopi tuli. Hal tersebut didukung dengan pernyataan (Rangkuti, 2002) bahwa ditengah persaingan bisnis saat ini upaya yang dapat dilakukan oleh pelaku bisnis adalah dengan menambah value, hal ini menandakan betapa pentingnya sebuah value dalam strategi komunikasi pemasaran dan saat ini sudah banyak diterapkan para pelaku bisnis. Oleh karena itu peneliti tertarik untuk meneliti staretgi komunikasi pemasaran terpadu yang dilakukan oleh coffee shop kopi tuli melalui penelitian yang berjudul "Strategi Komunikasi Pemasaran Terpadu Coffee Shop Kopi Tuli”

\section{B. Tinjauan Pustaka}

\section{Komunikasi Pemasaran}

Komunikasi pemasaran (marketing communication) adalah kajian baru dalam pemasaran yang saling berkesinambungan. Komunikasi pemasaran adalah kegiatan pemasaran dengan menggunakan sarana komunikasi yang bertujuan memberikan informasi perusahaan terhadap target pasarnya menurut (Priansa, 2017).

\section{Strategi Komunikasi Pemasaran}

Perusahaan dalam melakukan kegiatan pemasaran memiliki strategi masingmasing, dan untuk mencapai tujuan yang baik maka diperlukan strategi komunikasi pemasaran yang baik. Dalam kajian ini strategi komunikasi pemasaran menjadi kajian yang penting karena dalam mencapai tujuan komunikasi pemasaran yang ditetapkan oleh coffee shop kopi tuli perlu untuk dilakukannya strategi komunikasi pemasaran.

Adapun tahapan yang dapat dilakukan untuk melakukan strategi komunikasi pemasaran sebagi berikut:

\section{Perencanaan}

Ada beberapa langkah yang harus dilakukan pada tahapan perencanaan komunikasi menurut French \& Assifi dalam (Abidin, 2015) yaitu:

- Menganalisis masalah

- Menganalisis Khalayak

- Merumuskan Tujuan Komunikasi 


\section{- Pemilihan Media dan Saluran Komunikasi}

\section{Pelaksanaan}

Menurut (Amirullah, 2015) pelaksanaan merupakan suatu proses dalam mengelola sumber daya organisasi serta management melalui suatu strategi yang sudah dipilih. Pelaksanaan strategi tersebut perlu adanya dilakukan guna memandang bagaimana eksekusi yang sudah direncanakan.

\section{Evaluasi}

Pada langkah evaluasi melakukan pengecekan startegi yang telah dipilih sudah dijalankan dengan teratur, tepat serta dapat dimanfaatkan untuk masukan sebagai perencanaan strategi baru. Berdasarkan hal tersebut satu frekuensi dengan pendapat menurut Lawrence dan William dalam (Amirullah, 2015) yang berarti evaluasi merupakan langkah dalam proses strategi dalam memastikan bahwa strategi yang telah dipilih dapat terlaksana dengan tepat serta dapat mencapai tujuan perusahaan yang telah ditentukan.

\section{Komunikasi Pemasaran Terpadu (Integrated Marketing Communication)}

Menurut Taskforce American Association of Advertising Agencies (AAA) dalam Schults (1993), Ogden \& Ogden fan Belch \&Belch (2010) . IMC adalah pendekatan untuk mencapai tujuan kampanye perusahaan, yang menggunakan metode-metode promosi yang saling terkoordinasi dengan baik yang saling memperkuat dan memiliki nilai dari rencana komprehensif sebagai alat evaluasi bagi peran berbagai disiplin komunikas (Kotler, P.\& Keller, 2012) menjelaskan bahwa bauran komunikasai atau komunikasi pemasaran terpadu merupakan alat yang digunakan oleh perusahaan sebagai upaya dalam menginformasikan, membujuk dan mengingatkan konsumen secara langsung atau tidak langsung terkait produk dan merek yang dijual.

Menurut Suryanto (Suryanto, 2015) mengatakan bahwa komunikasi pemasaran terpadu merupkan bauran dari komunikasi pemasaran yang disatukan sehingga menjadi sebuah kekuatan baru yang sinergis dalam membangun dan menjaga hubungan yang bersifat jangka panjang bersifat saling menguntungkan bagi merek dan khalayak sasaran.

\section{Integrated Marketing Communication Model}

Adji watono dan Maya Watono dalam bukunya yang berjudul IMC That Sells, membahas prinsip-prinsip dasar sebagai faktor kunci bagi kesuksesan strategi dalam sebuah model. Model ini disebut dengan IMC Model Dwi Sapta yang digambarkan dengan tiga lingkaran (circle) diantaranya, Discovery Circle (lingkaran kiri), Intent Circle (lingkaran Tengah), Strategy Circle (lingkaran kanan) (Watono, A, Adji \& Watono, Maya, 2011) 


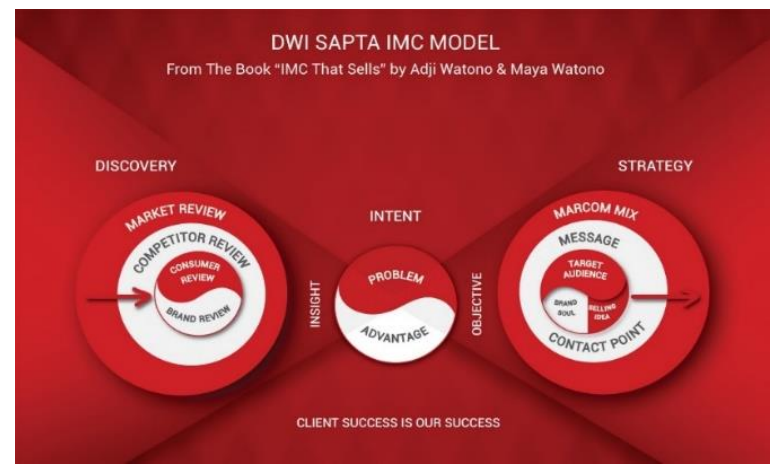

Sumber: Watono dan Watono (2011:78)

Gambar 1 : Integrated Marketing Communication Model Dwi Sapta

\section{Discovery Circle (Lingkar Kiri)}

Proses pertama dalam menyusun strategi komunikasi pemasaran (Integrated Marketing Communication) adalah mengeksplorasi berbagai kondisi lingkungan bisnis, yang bertujuan untuk menemukan ide-ide berharga (insight discovery) untuk mengembangkan kondisi merek yang berasal dari lingkungan internal dan eksternal bisnis, yaitu mencakup analisis terhadap pasar analisis berbagai aspek tren dan perubahan dipasar dari tren ekonomi dan industri (market review), analisis pesaing menganalisis pesaing untuk menghadapi persaingan di pasar berupa strategi dan langkah yang harus dilakukan oleh perusahaan (competitor review), analisis konsumen (consumer review), dan analisis mereknya sendiri analisis yang berhubungan eksternal produk/merek (brand review) (Watono, A, Adji \& Watono, Maya, 2011)

\section{Intent Circle (Lingkaran Tengah)}

Intent circle untuk mengetahui masalah (problem) dan keunggulan-keunggulan (advantage)yang dimiliki sebuah produk/merek berdasarkan hasil analisa pada lingkungan eksternal dan internal. (Watono, A, Adji \& Watono, Maya, 2011). Segala bentuk pengaruh negatif yang ada pada lingkungan eksternal dan internal berupa ancama (threat) dan kelemahan (weakness) adalah masalah (problem). Sebaliknya dengan segala pengaruh positif berupa peluang (oppurtunity) dan kekuatan (strength) dari sebuah keunggulan (advantage). Analisis pada tahapan intent circle ini bertujuan untuk memilah masalah dan keunggulan yang dihadapi oleh brand.

\section{Strategy Circle (Lingkar Kanan)}

Penyusunan strategi melihat dari dalam ke bagian luar lingkaranan perusahaan, bagian dalam dimulai dengan target yang ingin disasar. Setelah menentukan target audience langkah selanjutnya menentukan brand soul atau yang bisa menjadi pembeda dari brand, setelah itu menyusun selling idea berdasarakan brand soul yang sudah ditentukan, pesan, customer contact point dan yang terakir hasilnya berupa marketing mix (Watono dan Watono 2011:124). 
(a) Target audience (b) Brand soul. (c) Selling idea (d) Message (e) Contact point merupakan titik pertemuan dengan konsumen. (f) Marcom mix merupakan kegiatan pemasaran yang terintegrasi berupa pendekatan komunikasi menggunakan iklan, promosi penjualan, penjualan secara langsung. Semua pendekatan komunikasi haruslah berdasar pada "benamg merah" yaitu selling idea dan juga melaui pendekatan komunikasi dapat mengaktivasi contact point agar tepat sasaran dan efektif (Watono dan Watono 2011:153).

\section{Integrated Marketing Communication Model by David W Pickton and Amanda Broderick}

IMC dapat dikonseptualisasikan dalam kerangka kerja tiga terintegrasi dan model IMC yang saling terkait itu mewakili proses dimana komunikasi pemasaran terjadi cara mereka direncanakan dan alat dan teknik yang bisa digunakan untuk menerapkan IMC. Tiga model tersebut adalah IMC Process Model, IMC RABOSTIC Model dan The IMC Mix Model. Berikut Kerangka kerja:

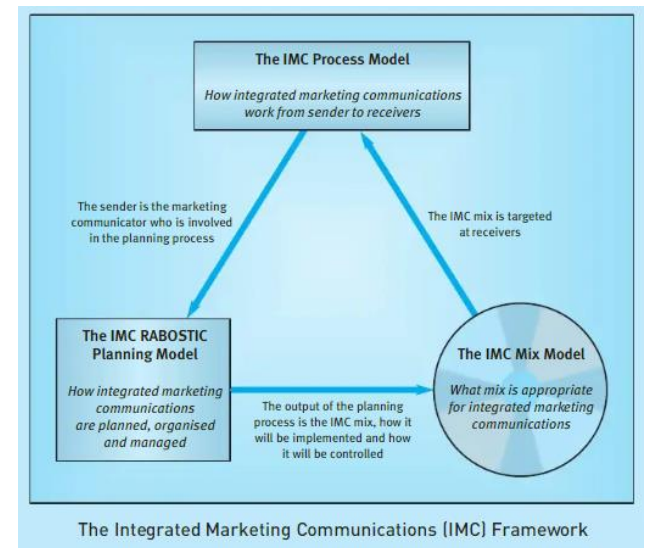

Sumber : (Pickton, 2005)

Gambar 2 : Frameworks IMC Model by David W Pickton and Amanda Broderick

\section{IMC Process Model}

IMC Process Model, sangat mendasar untuk memahami caranya pekerjaan komunikasi pemasaran dan didasarkan pada Schramm's klasik (1960) meskipun dengan sejumlah penambahan dan penyempurnaan yang signifikan untuk memberikan yang jauh lebih komprehensif kerangka kerja untuk memahami cara kerja komunikasi pemasaran. Pada model ini kegiatan yang dilakukan adalah menggambarkan bagaimana pemasaran arus komunikasi dari pengirim ke penerima dan seterusnya. Penerima dapat menjadi anggota target audiens yang dituju (termasuk pelanggan, konsumen dan pemangku kepentingan lainnya dan publik baik di dalam maupun di luar organisasi) dan anggota nonaudiens.Penerima dapat kemudian menyebarluaskan komunikasi lebih lanjut 
dengan orang lain. Secara semakin canggih 'Mediascape' (Hartley dan Pickton 1999), komunikasi tersebut akan mencakup penggunaan elektronik dan media non-elektronik dalam 'web' komunikasi sosial dan dalam mikro dan makro lingkungan komunikasi.

\section{IMC RABOSTIC Model}

Model ini membahas masalah perencanaan dan manajemen IMC yaitu menunjukkan siklus perencanaan yang pertama melibatkan penelitian dan analisis situasi dan umpan balik dari kampanye dan kegiatan komunikasi pemasaran sebelumnya dan rencana komunikasi harus merujuk pada audiens target yang banyak dan beragam karena alasan sebelumnya dijelaskan. Area siklus perencanaan membentuk akronim RABOSTIC: Research and analysis, Audience, Budgets, Objective, Strategies, Tactic, Implementation, dan Control. Setelah melakukan analisis terhadap RABOSTIC dari tahapan perencanaan selanjutnya pada tahap manajemen IMC, dimana arus informasi yang ada digunakan dalam proses perencanaan untuk membantu formulasi pemasaran terintegrasi rencana komunikasi. Di tengah model ini, penelitian dan pengambilan keputusan siklus menunjukkan analisis digunakan untuk memberi informasi pengambilan keputusan. Evaluasi berlangsung ketika rencana diterapkan.

\section{IMC Mix Model}

Pada model ini menggambarkan campuran komunikasi pemasara kegiatan yang dapat dimasukkan ke dalam IMC. Biasanya, promosi atau pemasaran campuran komunikasi telah diklasifikasikan ke dalam satu set empat item (misalnya, Hubungan Masyarakat, Periklanan, Promosi Penjualan, Penjualan Pribadi).

\section{METODOLOGI}

Penelitian ini menggunakan paradigma post positivistik. Paradigma ini sebagai dasar penelitian karena fenomena yang terjadi dan melihat realita yang timbul secara jamak, hal ini sesuai dengan pendapat (Salim, 2006) yang mengatakan bahwa post positivistik adalah aliran yang muncul untuk memperbaiki kelemahan dari positivisme yang hanya mengamati pengamatan terhadap objek yang diteliti. Jenis penelitian ini adalah deskriptif kualitatif, karena yang menjadi fokus peneliti adalah strategi komunikasi pemasaran coffee shop kopi tuli. Metode deskriptif kualitatif memiliki tujuan untuk mendeskripsikan dan menyimpulkan segala situasi maupun kondisi serta fenomena yang berada di sekitar lingkungan masyarakat yang menjadi objek penelitian (Burhan, 2007). 


\section{HASIL}

\section{Perencanaan}

Keufirman dalam (Atwari, B \& Widjajanto, 2013) menjelaskan bahwa perencanaan merupakan sebuah proses untuk menetapkan ke mana arah harus pergi dengan mengidentifikasi syarat apa yang harus dipenuhi untuk dapat menuju ketujuan tersebut, dengan cara yang paling efisien dan efektif, dengan kata lain perencanaan dapt diartikan sebagai penetapan cara-cara apa yang digunakan untuk dapat mencapai tujuan yang diinginkanPada tahapan perencanaan coffee shop kopi tuli melakukan beberapa kegiatan sebagai berikut:

a. Menganalisis masalah

Dalam perencanaan menganalisi masalah adalah hal penting yang harus dilakukan agar dapat ditemukan solusi menurut French \& Assifi dalam (Abidin, 2015). Coffee shop kopi tuli memulai tahap perencanaan yaitu dengan menganalisi masalah, dengan melihat kondisi market diluar dari perusahaan yang berpengaruh terhadap usaha, dari segi tren ekonomi yang sekarang terjadi yaitu maraknya orang-orang nongkrong di coffee shop kopi tuli dan juga kopi sebagai media bagi orang berinteraksi, kondisi ini dimanafaatkan oleh coffee shop kopi tuli untuk mengembangkan usaha. Coffee shop kopi tuli juga melihat krang diangkatnya isu sosial disabilitas di masyarakat dan coffee shop kopi tuli melihat ini sebagai masalah yang terjadi di masyarakat dan menjadi tujuan coffee shop kopi tuli melakukan kegiatan komunikasi pemasaran selanjutnya praktek yang dilakukan oleh coffee shop kopi tuli ini sesuai dengan aspek discovery circle yang ditawarkan oleh IMC Model Dwi Sapta hand (Watono, A, Adji \& Watono, Maya, 2011).

Langkah selanjutnya yang dilakukan oleh coffee shop kopi tuli yaitu mengalisis SWOT yang dimiliki yaitu, Keunggulan dari coffee shop kopi tuli adalah dari nama "kopi tuli", mempekerjakan teman-teman tuli, berkomunikasi dengan bahasa isyarat, bisa belajar bahasa isyarat. Kelemahan dari coffee shop kopi tuli adalah Kelemahan dari coffee shop kopi tuli menurut pengelola adalah hambatan komunikasi dalam melayani konsumen Ancaman sebuah usaha di pasar. Pengelola coffee shop kopi tuli mengatakan yang menjadi ancaman adalah banyaknya coffee shop yang memiliki pelayanan yang berbeda tetapi pengelola tetap optimis dengan keunikan yang dimiliki dan keingin untuk terus berkembang.

Menganalisis persaingan di pasar, dalam membandingkan daya saing pemain di dalam industri coffee shop pengelola membandingkan dari segi pembeda coffee shop lainnya dengan memperhatikan aspek lain dalam berbisnis misalnya yang dilakukan oleh coffee shop kopi tuli dengan adanya unsur sosial yang ingin dibangun, yaitu membuka lapangan pekerjaan sebanyak-banyaknya dan menjembatani komunikasi bahasa isyarat. 
b. Menganalisis Khalayak

Khalayak merupakan hal yang identik pada kegiatan komunikasi menurut (Atwari, B \& Widjajanto, 2013). Dalam menentukan khalayak atau target audience hal yang dilakukan oleh coffee shop kopi tuli adalah menentukan segmentasi pasar. Pada coffee shop kopi tuli yang menjadi target audience secara geo-demografis adalah masyarakat umum baik perempuan maupun laki-laki umur 16-50 tahun daerah jakarta fokusnya tapi juga seluruh Indonesia pekerja kantoran dengan pendapatan bebas. Target audience secara psikografis adalah yang suka jalan-jalan, yang suka belajar hal baru dan seluruh konsumen yang diwawancarai masuk dalam kriteri target audience coffee shop kopi tuli. Target audience secara sosiografis yang suka ngumpul dan suka nongkrong dan konsumen yang diwawancarai termasuk dalam kriteria ini juga. Target audience dari kebiasaan konsumsi yaitu yang suka mengkonsumsi kopi. penetapan target audiennce yang sesuai dengan konsep IMC Model Dwi Sapta yang menetapkan Segmentasi pasar dengan karakteristik yang sama, hal ini dari sisi geo-demografis, psikografi, sosiografis dan perilaku konsumsi (Watono, A, Adji \& Watono, Maya, 2011) dan juga sesuai dengan yang ditawarkan oleh IMC RABOSTIC Planning Model (Pickton, 2005) pada aspek penentuan audience.

\section{c. MerumuskanTujuan Komunikasi}

Dari yang dikemukan oleh Stanto dalam (Alo, 2011) bahwa terdapat sedikitnya lima tujuan utama, yang pertama adalah untuk mempengaruhi orang lain, membangun relasi, menemukan perbedaan jenis pengethauan, dan bermain atau bergurau.

\section{d. Pemilihan Media dan Saluran Komunikasi}

Komunikator pada kegiatan komunikasi pemasaran menetapkan saluran komunikasi yang memberi dampak terbesar dalam menyampaikan tujuan perusahaan menurut Sulaksana (2010). Pada penyebaran informasi terkait pesan yang disampaikan coffee shop kopi tuli fokus pada media sosial instagram sebagai contact point dengan konsumen, karena media sosial yang dimiliki oleh coffee shop kopi tuli adalah instagram dan konsumen dari coffee shop kopi tuli yang datang kebanyakan menggunakan media sosial instagram untuk digunakan dalam mencari informasi dan konsumen juga mengatakan bahwa informasiinformasi tantang coffee shop kopi tuli update di instagram. Pemilihan media instagram yang dilakukan oleh coffee shop kopi tuli adalah sebagai media penyampaia pesan dari coffee shop kopi tuli selaku komunikator, adanya pesan

yang disampaikan, menggunakan media, dan diterima oleh komunikan atau khalayak yang ingin dituju, proses ini sesuai dengan kegiatan yang dilakukan pada IMC Process Mix (Pickton, 2005). 
e. Pengembangan Pesan

Pengembangan pesan adalah isi atau maksud yang akan disampaikan kepada komunikan melalui media menurut Hermawan (2012). Pengembangan pesan yang dilakukan oleh coffee shop kopi tuli berangkat dari keunikan yang dimiliki pelayanan yang menggunakan bahasa isyarat, semua pengelola dan staff adalah tuli, coffe shop kopi tuli memberikan pengalaman kepada konsumen belajar bahasa isyarat yang secara tidak langsung adalah unique value proposition yang dimiliki oleh coffee shop kopi tuli menurut pengelola adalah dan berinteraksi dengan teman tuli dan yang menjadi titik pembeda adalah pengalaman yang berkaitan dengan tuli. coffee shop kopi tuli memiliki dan melakukan hal tersebut dan ini sesuai dengan konsep strategy circle pada aspek brands soul yang terdiri dari point of differentiation dan unique value proposisition yang ditawarkan oleh IMC Model Dwi Sapta (Watono, A, Adji \& Watono, Maya, 2011)

Setelah mengetahui keunikan dan hal yang paling beda dari coffee shop kopi tuli selanjutnya membuat tagline untuk menyampaikan pesan yaitu "the taste that touch your heart". Coffee shop kopi tuli melakukan pengembangan pesan dengan Tagline sebagai selling idea yang menjadi benang merah dalam kegiatan komunikasi pemasaran sesuai dengan konsep yang ditawarkan oleh IMC Model Dwi Sapta (Watono, A, Adji \& Watono, Maya, 2011).

\section{Pelaksanaan}

Dalam tahap pelaksaan ini coffee shop kopi tuli melakukan kegiatan komunikasi pemasaran, Ada delapan model bauran dari komunikasi pemasaran (marketing communication mix) (Kotler, P.\& Keller, 2012), (1) Sales Promotion, Coffee shop kopi tuli melakukan kegiatan sales promotion berupa potongan harga pada awal coffee shop buka selama satu minggu semua produk harganya Rp,16.000. (2) Personal selling, Coffee shop kopi tuli melakukan kegiatan personal selling yaitu berinteraksi langsung dengan konsumen dan menjelaskan pesan dari coffee shop kopi tuli melalui kegiatan-kegiatan berpartisipasi di berbagai acara setiap bulan setidaknya coffee shop kop tuli satu sampai tiga kali membuka booth, informasi mengenai coffee shop kopi tuli. (3) Humas dan Publisitas, Coffee shop kopi tuli melakukan kegiatan Humas dengan membuka ruangan dengan tujuannya mensosialisasikan bahasa isyarat, membangun ruang interaksi dan informasi tentang produk kegiatan humas ini dilakukan ketika coffee shop kopi tuli menjadi pembicara di workshop oleh kampus -kampus dan juga coffee shop kopi tuli juga memberikan sposnsor di workshop yang diikutinya. Publisitas yang dilakukan oleh coffee shop kopi tuli berupa kegiatan-kegiatan yang dilakukan dan diikuti oleh coffee shopkopi tuli disebarkan melalui media sosial instagram.(4) Event dan pengalaman, pengelola mengatakan bahwa coffee shop kopi tuli akan membuat acara "Koptul Back To 
Campus" di mana coffee shop kopi tuli akan datang ke kampus-kampus berupa diskusi dengan. Coffee shop kopi tuli juga ikut bekerjasama dengan komunitas-komunitas dan organisasi dalam membuat acara dan mengadakan kegiatan tersebut di coffee shop kopi tuli seperti kajian, nonton bareng, memperingati hari aids, kelas tata rias, belajar dengan teman downsyndrome.

Dari penjelasan diatas dapat diketahui bahwa coffee shop kopi tuli melakukan lima dari delapan bauran komunikasi pemasaran yang dipaparkan oleh (Kotler, P. \& Keller, 2012). Bauran komunikasi pemasaran yang dilakukan oleh coffee shop kopi tuli juga sesuai dengan aspek-aspek yang ditawarkan pada IMC Model Mix.

\section{Evaluasi}

Dalam tahap ini, coffee shop kopi tuli melihat dari pelaksanaan komunikasi pemasaran dengan melihat peningkatan jumlah pengikut media sosial instagram yang merupakan satu-satunya media pemasaran coffee shop kopi tuli untuk berbagi informasi terkait kegiatan komunikasi pemasaran yang dilakukan. Dimana terjadi peningkatan followers instargram dan juga instastory yang dibuat oleh coffee shop kopi tuli ini dilihat oleh konsumen sekitar 3000 sampai 5000 orang. Berdasarkan hal ini, coffe shop kopi tuli selalu mengukur kerja dari enggangament instagram, engagement menurut (Wijayani, 2016) adalah merupakan salah satu langkah yang dilakukan brand untuk mencapai tujuan untuk membangun hubungan baik dengan konsumen melaui platform .

\section{KESIMPULAN}

Pada tahapan perencanaan coffee shop kopi tuli, menganalisis masalah dengan melakukan analisis terkait market melihat dari aspek ekonomi bahwa sekarang kopi dapat dijadikan media komunikasi dan melalui coffee shop terciptanya ruang interaksi dan aspek sosial yang menjadi fokus utama dimana coffee shop kopi tuli berupa isu kesetaraan kaum disabilitas, dan analisis SWOT dengan Strength yang dimiliki yaitu pelayanan menggunakan bahasa isyarat, Weakness kendala komunikasi dalam pelayanan, Opportunity belum adanya coffee shop yang dikelola oleh kaum disabilitas tuli dan threatnya banyakanya coffee shop yang menawarkan pelayanan yang berbeda dari analisis ini. Menganalisi khalayak, target audience masyarakat umum baik perempuan maupun laki-laki umur 16-50 tahun daerah jakarta fokusnya, yang suka jalan-jalan, yang suka belajar hal baru. Merumuskan tujuan komunikasi teman-teman tuli juga bisa membuat usaha dan membuka ruang interaksi bagi teman-teman dengar dan teman-teman tuli melalui usaha coffee shop kopi tuli. Pemilihan Media dan Saluran Komunikasi adalah instagram. Pengembangan pesan berupa tagline "the taste that touch your heart".

Pada tahapan pelaksanaan melakukan kegiatan komunikasi pemasaran coffee shop kopi tuli manggunakan bahasa isyarat dan bauran kegiatan komunikasi pemasaran yang dilakukannya yaitu personal selling ketika berpartisipasi dalam sebuah acara untuk membuka booth, sales promotion dengan memberikan potongan harga, humas dan publisitas dengan menjadi 
narasumber untuk berbagi informasi tentang coffee shop kopi tuli, event dan pengalaman berupa event berkarya dalam sunyi, kajian, nonton bareng, memperingati hari aids, kelas tata rias, belajar dengan teman downsyndrome.

Pada tahapan evaluasi coffee shop kopi tuli melakukan tahapan mengukur kerja. Dalam mengukur kerja coffee shop kopi tuli melihat dari pelaksanaan strategi komunikasi pemasaran dengan melihat peningkatan jumlah pengikut media sosial instagram dan engagement yang merupakan satu-satunya media pemasaran coffee shop kopi tuli untuk berbagi informasi terkait kegiatan komunikasi pemasaran yang dilakukan. 


\section{DAFTAR PUSTAKA}

Abidin, Y. (2015). Manajemen Komunikas: Filosofi, Konsep, dan Aplikasi. Bandung: CV Pustaka Setia.

Adioetomo, S. M., Daniel Mont, \& Irwanto. (2016). Penyandang disabilitas di Indonesia: Fakta empiris dan implikasi untuk kebijakan perlindungan sosial. Lembaga Demografi Fakultas Ekonomi Universitas Indonesia, 1-9. Retrieved from http://www.asbindonesia.org/main/front/images/img_media/Penyandang Disabilitas di Indonesia_Fakta Empiris untuk Kebijakan Perlindungan Sosial (Bahasa Indonesia).pdf

Aliansyah, M. R., \& Ali, D. S. F. (2017). Strategi Komunikasi Pemasaran Melalui Media Instagram (Studi Kasus Forever Young Crew). E-Proceeding of Management, 4(3), 31233130.

Alo, L. (2011). Komunikasi Antar Personal. Jakarta: Remaja Rosdakarya.

Amirullah. (2015). Manajemen Strategi: Teori - Konsep - Kinerja. Jakarta: Mitra Wacana Media. Atwari, B \& Widjajanto, K. (2013). Perencanaan Komunikasi Konsep \& Aplikasi. Bandung.

Hermawan, A. (2012). Komunikasi Pemasaran. Jakarta: Erlangga.

Kartajaya, H. (2011). Marketing In Venus. Jakarta: Gramedia Pustaka Utama.

Kotler, P. \& Keller, K. L. (2008). Manajemen Pemasaran Jilid 1. Jakarta: Erlangga.

Maharani, S. (2018). Fenomena "Demam" Coffee shopdi Indonesia. Retrieved February 25, 2019, from https://kumparan.com/@kumparanfood/fenomena-mewabahnya-demam-coffeeshop-di-indonesia

Nilasari, S. (2014). Manajemen Stratgi itu Gampang. Cipayung: Dunia Cerdas.

Pickton, D. \& B. A. (2005). Integrated Marketing Communication 2nd ed. England: Pearson Education Limited.

Priansa, D. J. (2017). Komunikasi Pemasaran Terpadu. Jawa Barat: CV Pustaka Setia.

Rangkuti, F. (2002). Measuring customer satisfaction. Jakarta: PT. Gramedia Pustaka Utama Jakarta.

Shimp, T. A. (2003). Periklanan Promosi Aspek Tambahan Komunikasi Pemasaran Terpadu Jilid I. Jakarta: Erlangga.

Sulaksana, U. (2005). Intergrated Marketing Communication. Yogyakarta: Pustaka Pelajar.

Sulaksana, U. (2010). Integrated Marketing Communication : Teks dan Kasus. Bandung: Pustaka Pelajar.

Suryanto. (2015). Pengantar Ilmu Komunikasi. Bandung: CV Pustaka Setia.

Wahid, T. (2018). Pesan Kesetaraan dari Koptu (Kopi Tuli). Retrieved February 19, 2019, from http://www.cikopi.com/2018/12/pesan-kesetaraan-dari-koptul-kopi-tuli/

Watono, A, Adji \& Watono, Maya, C. (2011). IMC That Sells. Jakarta: PT Gramedia. 